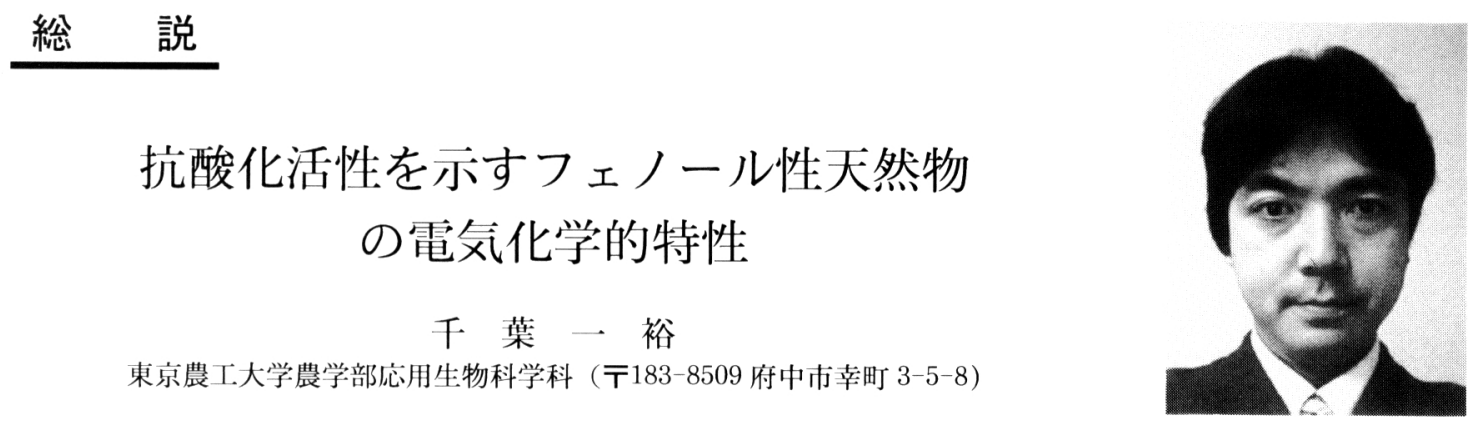

\title{
Electrochemical Characterization of Naturally Occurring Phenolic Antioxidants
}

\author{
Kazuhiro СніB A
}

Laboratory of Bio-organic Chemistry, Tokyo University of Agriculture and Technology

(3-5-8, Saiwai-cho, Fuchu-shi, Tokyo 183-8509)

\begin{abstract}
Many phenolic compounds are essential to the regulation of electron transfer and show antioxidative activity and/or biological activity. Some of these compounds therefore give rise to unstable intermediates through oxidation, which subsequently may be converted to related natural products. The electron transter and chemical reaction of phenolic compounds via oxidation process should play important role in the evaluation of their antioxidative property and biogenesis of phenolic metabolites. The electrochemical characterization of phenolic antioxidants including the compounds isolated from Eucalyptus spp are highlighted here.
\end{abstract}

Key words : antioxidant, phenol, euglobal, Eucalyptus, oxidation, biosynthesis

\section{1 はじめに}

食品にとって酸化は, 品質を低下させる代表的な要因 である。一方, 自然界に生育する植物は, 酸素や光の箃 しい条件の下に曝されており, 必然的にその防御策を講 じていると考えられる。また，そればかりではなく，む しろこの酸素や光により促進される化学反応（あるいは 生合成, 生分解反応) を皘極的に活用し, 多㥞な物質変 換やエネルギー変換を行うことにより，現在のところ未 知なる部分がまだ多く残される, 様々な生命現象を発現 していると考えられる。

筆者らは植物成分の酸化的な構造変化, 酸化的活性化 をキーステップとする生物活性物質の生合成反応や, 脂 質などの酸化を抑制する作用について電気化学的, ある いは生物有機化学的な見地から研究を行っている ${ }^{1) \sim 6) 。 ~}$ 酸化とは, 突き詰めれば電子の移動であるが, この過程 を制御することは, 新しい反応システムを構築し, より 高い機能を有する抗酸化物質を得る上で, 重要なことで あると考えられる。今回は, 主としてユーカリなど天然 に由来するフェノール系の化合物に焦点を当て, その酸 化による構造や反応性の変化, 抗酸化活性物質の化学構 造の特徴, 植物由来の新しい抗酸化活性物質の効率的な 探索方法などについて解説する。

\section{$2 \cdot 1$ フェノール性抗酸化物質の構造とその特性}

トコフェロール (1)（Fig. 1) はフェノール性天然抗 酸化物質として代表的なものであるが，天然からはすで に他にも多梯な抗酸化活性物質が分離されており，これ らはトコフェロールに匹敵するか，それを倰ぐ作用を示 すものもある7) 9)。一方，合成抗酸化物質としては BHA (2)，(3)，BHT (4) などが広く用いられている。

一般に BHA や BHT などの合成抗酸化活性物質は, 卜 コフェロールよりも強い抗酸化活性を示すが, フェノー ル特有の化学反応などによって共存する成分や生物との 相互作用を引き起こすことも考えられる。このような性 質は, フェノールの化学構造から予想されることが多 い。そこで，まずはじめに一見多様に見えるフェノール 系の化合物の, 酸化反応に伴う構造の変化, 酸化的活性 中間体の反応性について考えてみたい。

ある物質が酸化されるということは，電子を奪われる ことである。たとえば最も単純な，置換基を持たない フェノール (14) か酸化される場合, まず一電子酸化を 受けるとフェノキシラジカル (15) になり, さらに一電 子酸化によってカチオン (16) となる。水溶液中でこの 反応が進行すると, 水がこのカチオンを攻撃し, 二つの フェノール性水酸基を有するハイドロキノン（17）に変 化し，このハイドロキノンは，さらに二電子酸化によっ 
<smiles>Cc1c(C)c2c(c(C)c1O)CCC(C)(CCCC(C)(C)C)O2</smiles>

$\alpha$-tocopherol 1<smiles>COc1ccc(O)cc1C(C)(C)C</smiles>

2-BHA<smiles>COc1ccc(O)c(C(C)(C)C)c1</smiles>

3-BHA 3<smiles>Cc1cc(C(C)(C)C)c(O)c(C(C)(C)C)c1</smiles>

BHT 4<smiles>CC(C)c1cc2c(c(O)c1O)[C@]13CCCCC(C)(C)[C@H]1CC2O3</smiles>

carnosol 5

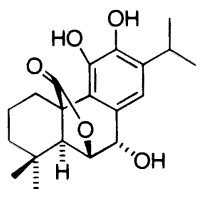

rosmanol 6<smiles>CC(C)C1=CC2=C(C(=O)C1=O)[C@@]1(C)CCCC(C)(C)[C@H]1CC2</smiles>

rosmariquinone 7<smiles>Oc1cc(O)c2c(c1)OC(c1ccc(O)c(O)c1)C(O)C2c1c(O)cc(O)c2c1OC(c1ccc(O)c(O)c1)C(O)C2P</smiles>

tannine 8

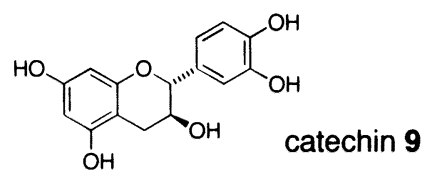<smiles>COc1cc(O)c2c(=O)cc(-c3ccc(O)cc3)oc2c1</smiles>

5,4'-dihydroxy-7-methoxyflavone 10<smiles>O=C(O)c1cc(O)c(O)c(O)c1</smiles>

gallic acid 11<smiles>O=C(O[C@H]1Cc2c(O)cc(O)cc2O[C@H]1c1cc(O)c(O)c(O)c1)c1cc(O)c(O)c(O)c1</smiles><smiles>O=c1oc2c(O)c(O)cc3c(=O)oc4c(O)c(O)cc1c4c23</smiles>

elaidic acid 13

Fig. 1 Structures of some phenolic antioxidants.

てキノン (18) に変化する。このように単純なフェノー ルでもキノンになることにより四電子放出することがで きる。

次に, より酸化されやすい， あるいはより酸化されに くいフェノールとはどのようなものであるかという点に ついて, 系統的に理解する必要がある。フェノールは置 換基の種類や位置関係によって生成物や中間体の構造, 安定性は大きく異なり, キノン, キノンモノケタール (19), キノンメチド (20)などに変換された後, 他の分 子と反応することが多い。たとえばフェノール性水酸基 のパラ位，またはオルト位に水酸基を有するものは，二 電子酸化を経て, パラまたはオルトベンゾキノンへと変 換される。また同じ位置に，水酸基の代わりにアルコキ シル基が存在するものでは, 酸化の過程でアセタール構 造を有するキノンモノケタールなどに変換され, その後 加水分解, またはアルコールの脱離によってキノンに変
換される。この反応は, トコフェロールの酸化過程など で確認されている。さらに, フェノール性水酸基のパ ラ, またはオルト位にアルキル基が結合している場合に は, 酸化反応の進行と供にキノンメチドが形成される。 アビエタン骨格を有するジテルペン (21) などからは数 種類のキノンメチド体 (22) が分離されており, 同様の 酸化経路を経て生成したものと考えられる。また, 多く の場合この中間体は水などによる求核攻撃を受けること により，アルコール等の官能基を新たに有した物質へと 変換される。また, フェノールに特有のラジカルカップ リング反応等による二量化も多く見られる。

それではこのような数多くのフェノール類の酸化反応 はどのようにして予想し, 評価することができるであろ うか。ある化学物質を酸化する時には多くの場合, 酸化 剂を用いる(その酸化剂が空気であることもある)。こ のとき, その酸化剤によって酸化を受けるかどうかは酸 

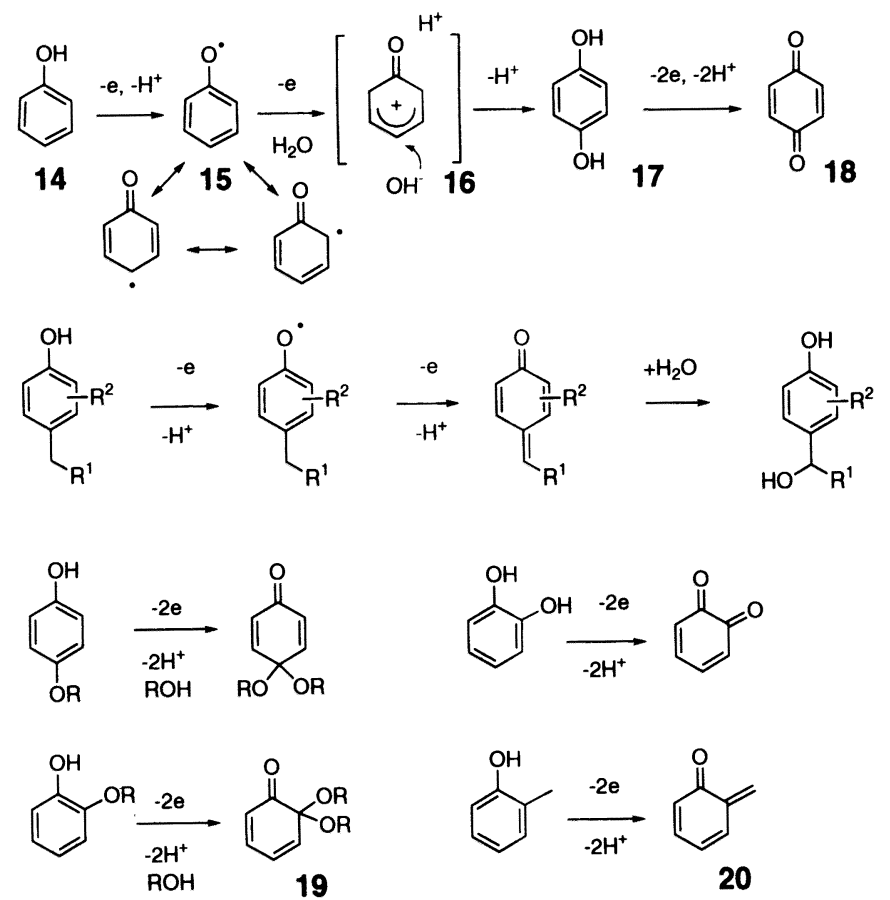

Fig. 2 Oxidation process of varied phenolic compounds.

化されやすい物質であるかどうかの一つの指標になる。 フェノールは一般的には酸化されやすい物質であると理 解されるが，これは，Fig. 2 に示すように，一電子酸化 によってラジカルへと変換されたときの中間体 (15) が 共鳴安定化するためである。特に, 電子供与基を多く有 するものではより安定になる。

このようなラジカルの生成は先に示した, いくつかの 置換基を有するフェノールでもそれぞれ見られ，キノン などに変換される第一段階として経由するステップとな る。しかし, 個々のフェノールについてその性質を比較 すること, あるいは予測することはなかなか困難なこと である。そこで, 我々は電気化学的な方法を用いること によって, フェノール類の電子の放出しやすさを系統的 に解析しようと考えた。Fig. 4 には置換基を有する八 イドロキノン (23) の典型的なサイクリックボルタモグ ラムを示す。この方法では, 上向きおよび下向きのピー ク位置から, それぞれ酸化および還元過程が明らかにな る。フェノール類の酸化還元電位を測定すると, 特にホ ルミル基やアセチル基など, 電子求引性の置換基を有す るフェノール類では酸化電位が高いことがわかる。この ようなフェノールは酸化されにくく, 酸化により生成し た物質は一般には不安定であり, 様々な化学反応に関与 することが多い。一方, アルキル基, アルコキシル基な ど, 電子供与性の置換基が結合したフェノール類では酸
化電位は低く，酸化されやすい性質を示す。

この手法を用いて化学合成によって得た天然物アナログ の酸化電位を測定した (Fig. 5)。その結果, 電子供与 性の水酸基を三つ有するフロログルシノールでも他に電 子求引基を有するものは酸化電位が高い一方で, 電子求 引基の数が減少すれば, 酸化電位は低くなる。また, 夕 ンニンのアナログとして合成した (30) などのようにべ ンジル位の活性なメチン基を有するものでは酸化電位が 極めて低いことがわかった。またこの物質では還元ピー クも顕著に観測され, 酸化還元過程が可逆的に進行する ことも示された。これは, カテキンが酸化的に重合して ベンジル位にフェニル基が結合することにより生成した タンニンは, 酸化電位が低下し, 優れた抗酸化活性を示 すようになることを定性的に示すものである。

\section{$2 \cdot 2$ フェノール類の酸化反応を経由した構造変換}

これまでにフェノールの酸化のプロセスから抗酸化活 性との関連について一般的な知見を述べたが，このよう な酸化過程は生物の中でも巧みに利用され，ある時には 脂質成分などの酸化の抑制に，またある時には様々な有 用物質の生産に利用している。そこで次に, ユーカリ中 に多量に含まれる様々な構造を有するフェノール性天然 物を例にして, 酸化に伴うフェノール類の多様な構造変 換について示す。

コアラの食物として有名なユーカリは，実際には 3 


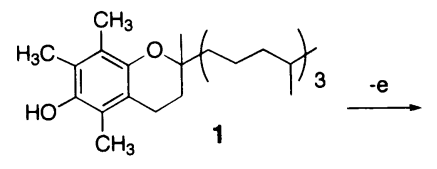<smiles>COc1c(C)c(C)c2c(c1C)CCC(C)(CCCC(C)(C)C)O2</smiles><smiles>CC1=C(C)C(=O)C(CC(C)(C)CCCC(C)C)=C(C)C1=O</smiles><smiles>CC1=C(C)C(C)(O)C(C)=C(C)C1=O</smiles>

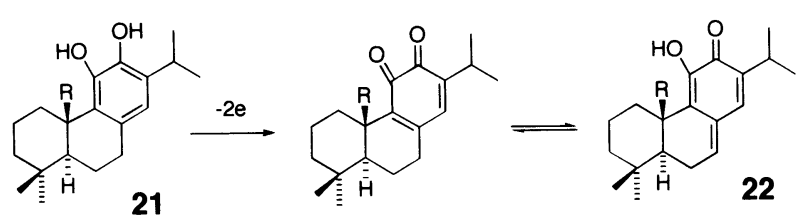

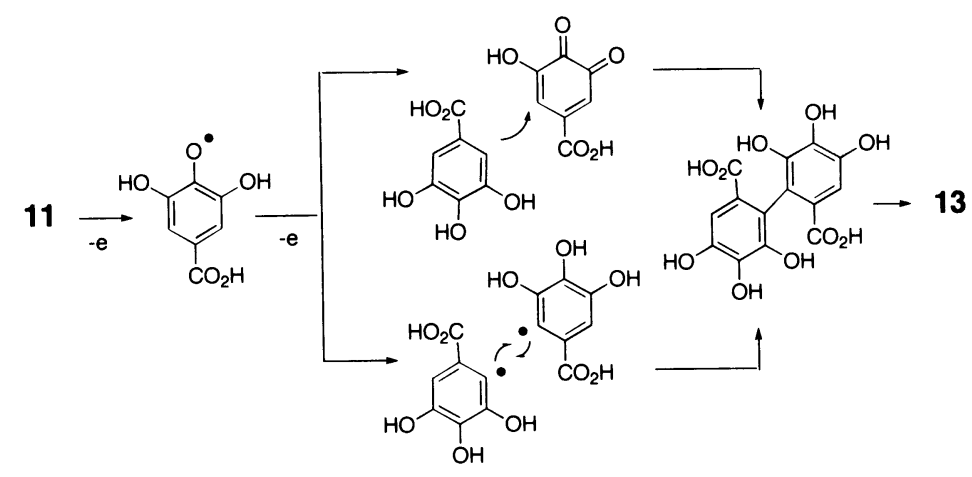

Fig. 3 Proposed oxidation process of phenolic antioxidants.

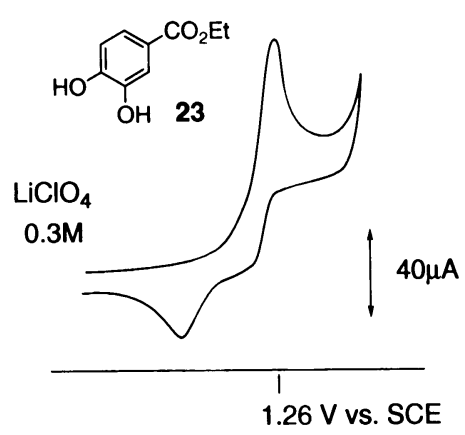

sample: $1.0 \mathrm{mg} / \mathrm{ml} \mathrm{CH}_{3} \mathrm{NO}_{2}$

SR: $50 \mathrm{mV} \mathrm{sec}^{-1}$

WE: glassy carbon

$\mathrm{CE}: \mathrm{Pt}$

RE: SCE

Fig. 4 Cyclic voltammogram of ethyl 3,4-dihydroxybenzoate.
4 属 800 種類以上の種が存在する。このユーカリには多 量の油が含まれており，ユーカリ油の起源としても，あ るいは木材, 紙の原料としても人間生活に密着した植物 である。そればかりではなく，古来よりユーカリは万能 薬として注目されており, 葉の熱水抽出物には消毒作 用, かゆみ止め作用などがある他, 熱帯地方ではマラリ ア，赤痢などに対する薬効があることが広く知られてい る。また, ユーカリの多くは葉を食べる害虫に対する抵 抗性が強いなど, 植物としての自己防御機能にも優れ, 様々な生物活性物質を生産していることも容易に予測で きる。このような背景もあって, 近年ユーカリの中で も, とりわけユーカリノキ属 (Eucalyptus) の植物か ら, 様々な化学物質が単離, 構造決定された。これらの 成分の多くはフロログルシノールを基本とするフェノー ル性の物質である。そして，このフロログルシノールを 基本とした物質が, 極めて多様な構造となって存在して いることがユーカリ成分の大きな特徴と言える。

ユーカリには多量の油が存在しているため, 抗酸化活 性を有する物質も多く含まれていることが予想される。 

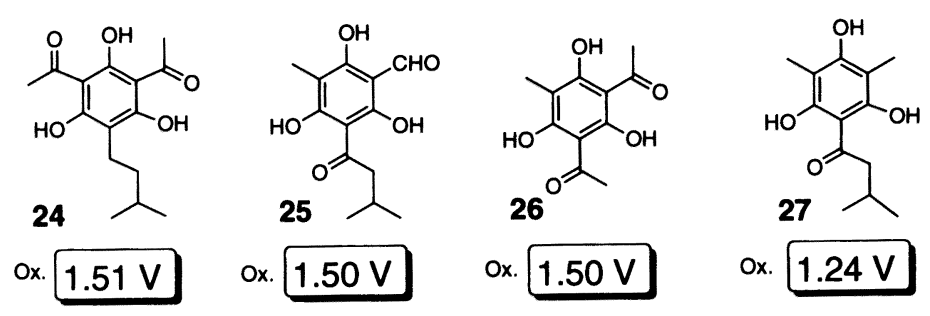<smiles>CCc1c(O)cc(O)c(CC)c1O</smiles>
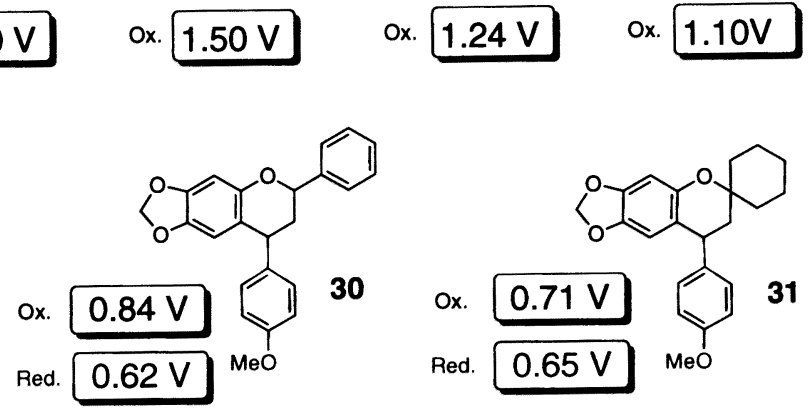

\section{Oxidation potentials vs. SCE in $1 \mathrm{M} \mathrm{LiClO} / \mathrm{CH}_{3} \mathrm{NO}_{2}$ Anode (W) : glassy carbon Cathode(C): Pt}

Fig. 5 Oxidation potentials of natural phenolic compounds and their analogues.

実際のところ，ユーカリから見いだされているフロログ ルシノール誘導体の中には, 低い酸化電位を示すものも 多く，(48）などは，抗酸化活性物質としても優れた作 用があると考えられる。また，ユーカリの成分で興味深 いことは, フェノール成分が酸化されるプロセスをその まま多様な二次代謝産物の生産に利用していることであ る。Fig. 7 に，ユーカリに含まれるフェノール性物質 の予想される生合成経路を示した。これらのフェノール 成分は，ポリケタイドの Claisen 縮合および芳香環の メチル化を経て, 酸化的に変換されて生成する。最初の 酸化プロセスは (27) のベンジル位の酸化である。この 物質を化学合成によって得た後, 酸化電位を測定したと ころ $1.24 \mathrm{~V}$ であり，比較的酸化され易い物質であるこ とが確認され，容易に (25)，(53）などに変換されると 考えられる。

一方，ユーカリからは，さらに酸化されたプロセスを 経て生成した，ユーグロバール (32)-(38), (41)-(45)あ るいはロブスタジアール (39), (40) と呼ばれる, 一連 の生理活性物質が分離, 構造決定されている ${ }^{10) \sim 14) 。 ~}$ これらの物質は, $\mathrm{EB}$ ウィルスによる皮慮プロモー 夕ーの活性化を抑制する作用や抗マラリア活性を示す一 方で, その特異な化学構造から生合成反応機構にも関心 が高まっている。すなわち, ポリフェノール（多価フェ ノール）の一種であるフロログルシノール誘導体とテル ペン類が付加環化反応することにより生成すると予想さ れる。このような反応を経由しているとすると, 反応途 中でフロログルシノール誘導体から酸化的にキノンメチ
ドが生成し，この不安定な中間体がテルペンと反応して いることになる。この反応はホルミル基, あるいはアシ ル基など, 電子求引性の置換基を二つ有するため, 酸化 電位が高くなる。それではこのような酸化電位が比較的 高いフェノールはどのように酸化されるのであろうか。 まずはじめに, 電極を用いて種々の条件下, 直接酸化的 にキノンメチドに変換することを試みた。この物質は過 塩素酸リチウムを支持塩としたニトロメタン溶液中では $1.50 \mathrm{~V}\left(\mathrm{Et}_{4}\right.$ NOTs を支持塩とした時には $\left.1.25 \mathrm{~V}\right)$ であ り,この電解電位で酸化したところ, 目的とする反応は 全く進行せず，分解反応だけが起こった。そこで新た に，より酸化電位の低いものを介して電子を奪う方法に ついて探索することにした。すなわち，(63）よりも酸 化電位が低いフェノールであっても, 生じた中間体の酸 化力が強く, この化合物から電子を奪う作用があれば, 酸化還元メディエーターとして作用することにより, 最 終的には容易に酸化物を得られるのではないかと期待し た。このような観点から様々なフェノール性物質を探索 したところ 2,3-dichloro-5,6-dicyano-p-hydroquinone (DDHQ) (62) に優れたメディエーターとしての作 用があることが明らかになった。この物質のサイクリッ クボルタモグラムを測定すると, (63) よりも酸化電位 は遙かに低く、また酸化波が二つのピークとして観測さ れた。これは, 第一酸化波が最初の一電子移動によるラ ジカルの生成を示していると考えられ，第二酸化波が二 電子目の移動によるキノンへの変換過程を示している。 そこで，わずかな DDHQ 存在下，第一酸化波の電位よ 


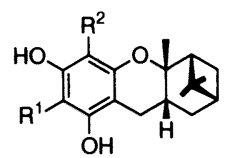

32 euglobal G1 $\left\{\begin{array}{l}R^{1}=\mathrm{CHO} \\ R^{2}=\mathrm{COCH}_{2} \mathrm{CH}\left(\mathrm{CH}_{3}\right)_{2}\end{array}\right.$ 33 euglobal G2 $\left\{\begin{array}{l}R^{1}=\mathrm{COCH}_{2} \mathrm{CH}\left(\mathrm{CH}_{3}\right)_{2} \\ R^{2}=\mathrm{CHO}\end{array}\right.$<smiles>[R]c1c(O)c([R])c2c(c1O)C[C@H]1C[C@H](C(C)C)C=C[C@]1(C)O2</smiles>

36 euglobal $T 1\left\{\begin{array}{l}R^{1}=\mathrm{CHO} \\ R^{2}=\mathrm{COCH}_{2} \mathrm{CH}\left(\mathrm{CH}_{3}\right)_{2}\end{array}\right.$ 37 euglobal Ilc $\left\{\begin{array}{l}R^{1}=\mathrm{COCH}_{2} \mathrm{CH}\left(\mathrm{CH}_{3}\right)_{2} \\ R^{2}=\mathrm{CHO}\end{array}\right.$

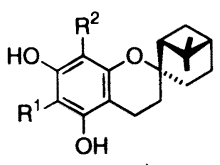

34 euglobal G3 $\left\{\begin{array}{l}R^{1}=\mathrm{CHO} \\ \mathrm{R}^{2}=\mathrm{COCH}\end{array}\right.$

35 euglobal G4 $\left\{\begin{array}{l}R^{1}=\mathrm{COCH}_{2} \mathrm{CH}\left(\mathrm{CH}_{3}\right)_{2} \\ R^{2}=\mathrm{CHO}\end{array}\right.$

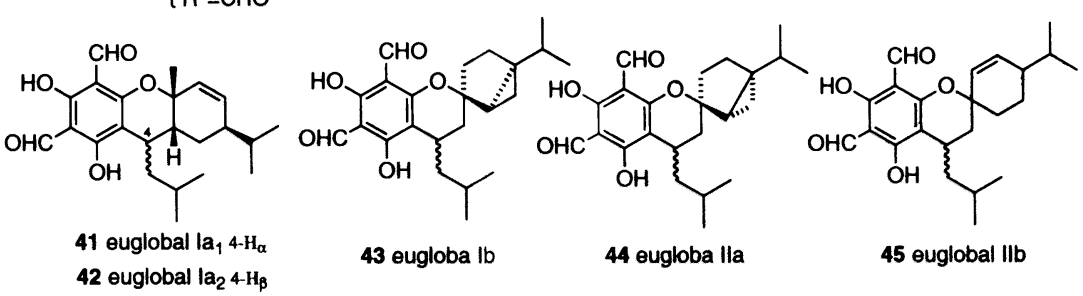<smiles>COc1cc(O)cc(O)c1C(=O)C(C)C</smiles><smiles>COc1cc(O)c(C(=O)C(C)C)c(O)c1C</smiles><smiles>COc1c(C)c(OC)c(C(=O)CC(C)C)c(OC)c1C</smiles>

48 torquatone<smiles>Cc1c(O)c(C=O)c(O)c(C(=O)CC(C)C)c1O</smiles>

25 grandinol<smiles>COc1c(C)c(O)c(Cc2c(O)c(CO)c(O)c(C(=O)CC(C)C)c2O)c(O)c1C(=O)CC(C)C</smiles>

49 robustaol $A$

Fig. 6 Structures of natural englobals and related compounds isolated from Eucalyptus spp.

りも低い電解電位に設定し，（25）の酸化を試みたとこ ろ,このような低い電位でも酸化反応が進行し, 各種テ ルペンを共存させた場合は, キノンメチドを経由して生 成したと考えられる生理活性天然物をフラスコ内で高い 収率で得ることに成功した。

これらの結果は, 適切なメディエーターと酸化を受け る基質を組み合わせることによって，このメディエー ター自身が優れた抗酸化作用を微量で示すようになると いう可能性を示すものである。ユーカリ自身が何らかの メディエーターを用いてユーグロバールの生合成に至る 最終段階の反応を行っているかどうかについては未だ解 明されていないが, 酸化電位の高い基質に対して, より 低い電位で酸化が進行して生成物ができる経路があるこ
とは明らかであり, 酸化電位の高いフェノール性化合物 でも, 酸化還元メディエーターとの組合せによっては容 易に酸化されることを示すものである。

\section{3 優れた抗酸化剂の探索}

これまで, フェノール類の酸化反応における電子移動 過程, 構造変化について述べてきたが, それでは優れた フェノール系抗酸化物質として必要な性質はどのような ものであろうか。一つには酸化還元電位が低いことが望 ましく, さらに電子移動過程が可逆であること, 酸化状 態の安定性が高いこと, 他の分子との反応性が低いこと などの条件があげられる。また，ユーカリ成分の酸化反 応過程を例に示したように，たとえ酸化電位が高いもの 


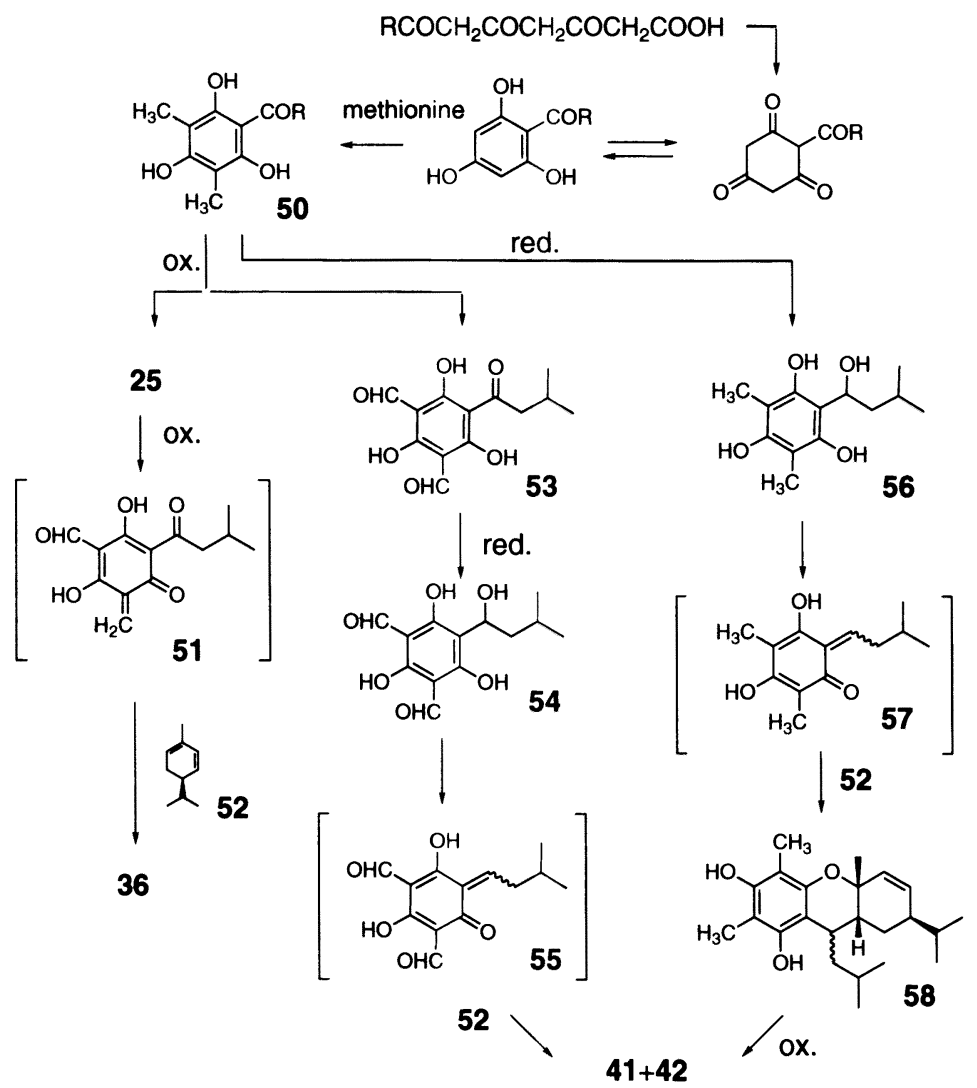

Fig. 7 Proposed biogenetic pathway of phenolic compounds in Eucalyptus spp.<smiles>Cc1c(O)c(C)c(O)c(C(=O)CC(C)C)c1O</smiles>

27<smiles>CC1=C(O)C(=CCO)C(O)=C(C(=O)CC(C)C)C1=O</smiles>

59

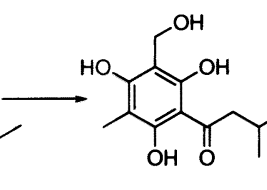

60<smiles>CCCCCCCCC</smiles>

25

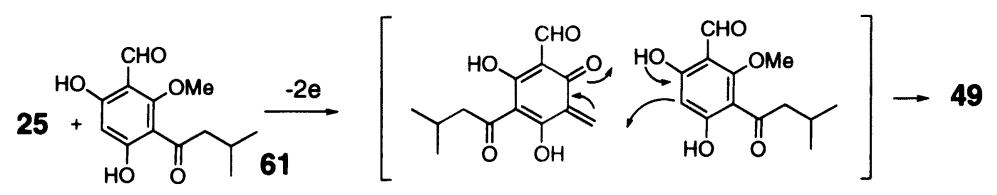<smiles>C=c1c(O)c(C(=O)CC(C)C)c(O)c(CO)c1=CC1=C(C)C=CC(C(C)C)C1</smiles>

Fig. 8 Proposed generation mechanism of quinone methides by the oxidation of phenolic metabolites. 


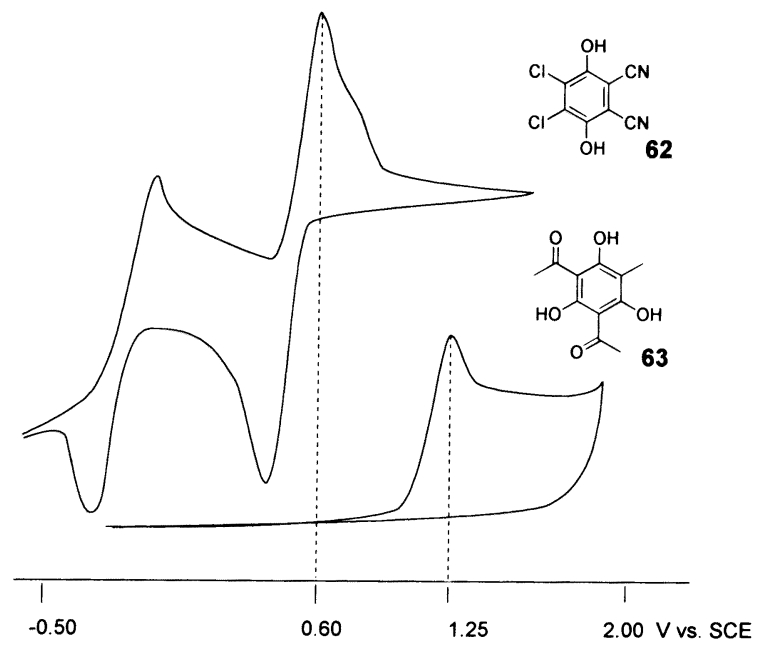

Fig. 9 Cyclic voltammograms of DDQ and pholoroglucinol derivatives in $50 \mathrm{mM}$ of $\mathrm{Et}_{4} \mathrm{NOTs}$ in $\mathrm{CH}_{3} \mathrm{NO}_{2}$.

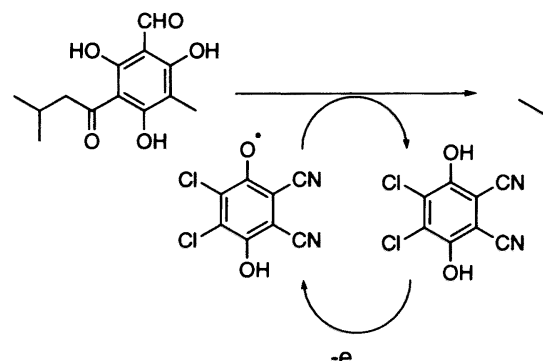

$-e$

$-2 e$ (0.45 V vs. SCE)<smiles>Cc1c([O])c(C(=O)CC(C)C)c(O)c(C=O)c1O</smiles>

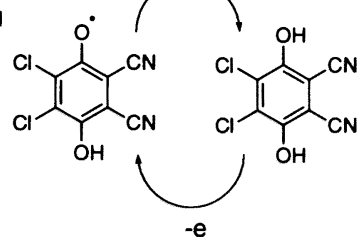<smiles>C=C1C(=O)C(O)=C(C(=O)CC(C)C)C(O)=C1C=O</smiles>

$32+33$ (1:1) Yield $89.3 \%$

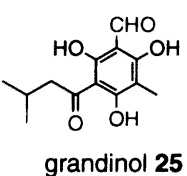
$\underset{\mathrm{DDQ}}{\mathrm{Dt}(0.2 \mathrm{eq})}{ }_{4}{ }^{(+)-\beta \text {-pinene }}$ $\left(0.45^{-2 e}\right.$ V vs. SCE $)$ $36+37(9: 5)$ Yield $78.6 \%$

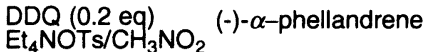

Fig. 10 Electrochemical synthesis of natural euglobals using a redox mediator.

が最終的な電子供与体となったとしても，ここに介在し て電子移動を進める物質が存在するならば，このメディ エーターこそが再生可能な抗酸化剂になる可能性もあ る。このような物質を天然から探索するための方法とし て, サイクリックボルタンメトリー $(\mathrm{CV})$ 法に注目し ている。この方法を用いると, 酸化還元電位の他, 酸化 還元反応を繰り返した時の, 波形形状の変化から, ある 物質の電子移動過程の可逆性, 酸化状態の安定性を評価 することができるため, 複数の分子の組合せによって作 用を示す抗酸化剂を探索するのにも好都合である。ま た，他の成分が共存しても，酸化還元反応を示す物質を
高感度に, 短時間で検出することができる。これまでに ユーカリなど, フトモモ科植物や青シソなどシソ科植物 に含まれるフェノール系物質の電気化学的特性を調べる ことにより，これらに優れた抗酸化活性があることを確 認した ${ }^{15) \sim 17) 。 ~}$

\section{4 おわりに}

植物は自己防御の手段として抗酸化活性物質を生産し, 巧みに利用している。その多くは, 産業上も有用であ り, 実際に単一物質, 粗抽出物の形で, あるいは食品の 原料成分の機能をそのまま活かす形で利用されている。 
また，一方で化学合成によって得られた抗酸化物質には 優れた活性が見られながら, 大量に使用したときの問題 点なども指摘され, 天然由来の新しい, 強い活性を有し た物質への期待は大きい。このような天然抗酸化物質は 今後も, 多数の物質が見いだされると予想されるが, 天 然物をヒントに, より優れたものを天然物から変換して 得るということも新たな取り組みとして必要なことでは ないかと考えられる。これまで, 述べたように優れた抗 酸化活性を示すフェノールの, 構造的, 電気化学的な特 性が明らかになってきた。これらの特性を有する物質の 原料は植物界に多く認められ, きわめて簡単な構造変換 によって達成することができるものが多い。また，この 構造変換によって, 抗酸化活性の増加ばかりでなく, 色, 臭い, あるいは有害な性質の低減, 安定性の増加 等, 産業上必要となる機能をもたせることが可能になる と考えられる。

\section{謝辞}

本研究は文部省科学研究費 (重点領域研究 No. 283), (財)飯島記念食品科学振興財団, 三栄源食品化学研究振 興財団ならびに(財)旗影会の研究助成により行われた。

(受付: 1998 年 4 月 20 日, 受理 ; 1998 年 6 月 6 日)

\section{文献}

1) K. Chiba, M. Tada, J. Chem. Soc., Chem. Commun., 1994, 2485.

2) K. Chiba, J. Sonoyama, M. Tada, J. Chem. Soc., Chem. Commun., 1995, 1381.

3) K. Chiba, J. Sonoyama, M. Tada, J. Chem. Soc., Perkin Trans. 1, 1996, 1435.
4) K. Chiba, T. Arakawa, M. Tada, Chem. Commun., 1996, 1763.

5）千葉一裕, 多田全宏, 有機合成化学協会誌, 54, (8), 686 (1996).

6) K. Chiba, M. Jinno, A. Nozaki, M. Tada, Chem. Commun., 1997, 1403.

7) T. Kawada, T. Watanabe, T. Takahashi, T. Tanaka, K. Iwai, Proc. Soc. Exp. Biol. Med., 183, 250 (1986).

8) T. Kawada, S. Sakabe, T. Watanabe, M. Yamamoto, K. Iwai, Proc. Soc. Exp. Biol. Med., 188, 229 (1988).

9) T. Kawada, K. Iwai, Agric. Biol. Chem., 49, 441 (1985).

10) M. Kozuka, T. Sawada, F. Kasahara, E. Mizuta, T. Amano, T. Komiya, M. Goto ; Chem. Pharm. Bull., 30, (6), 1952 (1982).

11) M. Kozuka, T. Sawada, E. Mizuta, F. Kasahara, T. Amano, T. Komiya, M. Goto, Chem. Pharm. Bull., 30, (6), 1964 (1982).

12) M. Takasaki, T. Konoshima, K. Fujitani, S. Yoshida, H. Nishimura, H. Tokuda, H; Nishino, A. Iwashima, M. Kozuka, Chem. Pharm. Bull., 38, (10), 2737 (1990).

13) M. Kokumai, T. Konoshima, M. Kozuka, J. Natl. Products, 54, (4), 1082 (1991).

14) M. Takasaki, T. Konoshima, M. Kozuka, M ; Haruna, K. Ito, S. Yoshida, Chem. Pharm. Bull., 42, (10), 2177 (1994).

15) M. Tada, T. Hara., C. Hara, K. Chiba, Phytochemistry, 45, (7), 1475-1477 (1997).

16) M. Tada, R. Matsumoto, H. Yamaguchi, K. Chiba, Biosci. Biotech. Biochem., 60, (7), 1093-1095 (1996).

17) M. Tada, R. Matsumoto, K. Chiba, Phytochemistry, 43, (4), 803 (1996). 


\section{日本油化学会誌本号掲載 論文要旨}

[総説 $]$

\section{抗酸化活性を示すフェノール性天然物の \\ 電気 化 学 的 特 性}

千 葉一裕

東京農工大学農学部応用生物科学科（开183-8509 府中市幸町 3-5-8)

天然には様々なフェノール性物質が存在し, 多様な生物活性を示す他, 有用な機能を持つ物質も多数知られてい る。とりわけフェノール性物質は，電子移動過程に関与し，酸化還元反応などに重要な役割を果たすものも多い。 また，酸化的に活性化された状態では，高い反応性を示し，多くの関連化合物に変換されることがある。このよう なフェノール類の酸化的な反応過程は, 抗酸化活性の発現機構や, 多様な生物活性物質の生成過程を考える上でも 重要なステップとなると考えられる。今回, 天然由来の抗酸化活性物質やユーカリに含まれるフェノール性化合物 に焦点をあて, それらの生成機構, 酸化過程における活性中間体の反応性についての電気化学的な特性解析法に関 する筆者のこれまでの研究を中心に解説する。

フェノールは置換基の種類およびその結合位置によって性質が大きく変化する。特に電子供与性の置換基を多く 持つものは低い酸化電位を示し，電子を放出することによって，フェノキシラジカルを経てキノン，キノンメチ ド, キノンモノケタールなどに変換される。この電子の放出しやすさは電気化学的に評価できる。また, 酸化電位 の高いフェノールも適切な酸化還元メディエーターが存在すれば低い酸化電位で酸化することができる。優れた抗 酸化剂は電子を容易に供与する他, 酸化状態が安定であること, 電子移動について可逆であることなどが重要であ る。これらの性質を解析する上で電気化学的な方法は重要な役割を果たすと考えられる。

(連絡者: 千葉一裕) Vol. 47, No. 8, 743 (1998)

\section{［報文］オゴノリによるプロスタグランジンの生産}

中島 一郎 ${ }^{* 1} \cdot$ 砂崎 和彦*2 $\cdot$ 大場 健吉*3

*1 ライオン株式会社研究開発本部生物科学センター（开 256-0811 神奈川県小田原市田島 100）

*2 ライオン株式会社薬事部 (广130-0004 東京都墨田区本所 1-3-7)

*3 ライオン株式会社研究開発本部（テ132-0035 東京都江戸川区平井 7-13-12）

寒天の原料として汎用される紅藻類の海藻オゴノリ (Gracilaria verrucosa) は, 海に生息している状態ではプ ロスタグランジン $(\mathrm{PG})$ を含まない。しかし, 物理的刺激を受けると, 藻体内に保有する酵素と基質を利用して 多量の PG を生成した。

$\mathrm{PG}$ 生成量は乾重量あたり約 $2 \mathrm{~g} / \mathrm{kg}$ に達し、組成の $90 \%$ は $\mathrm{PGE}_{2}$ であった。生成される $\mathrm{PG}$ 組成は、藻体に 含まれる高度不飽和脂肪酸の組成を反映するが，各 PGに対応した前駆体の添加により制御可能であった。

オゴノリの単藻培養により, この海藻自身が PG を生成することを確認した。また, 数種のオゴノリ近縁種に 少量の $\mathrm{PG}$ 生成が認められた。

（連絡者: 中島一郎）Vol. 47, No. 8, 753 (1998) 